\title{
Rerupture of nonparasitic liver cyst treated with cyst fenestration: a case report
}

\author{
Kentaro Inoue ${ }^{1,2^{*}}$, Tomohiro Iguchi ${ }^{2}$, Shuhei Ito ${ }^{2}$, Takefumi Ohga ${ }^{2}$, Tadahiro Nozoe ${ }^{2}$, Ken Shirabe ${ }^{1}$,
}

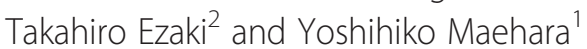

\begin{abstract}
We herein describe a case involving spontaneous rerupture of a nonparasitic liver cyst successfully treated with cyst fenestration and an omental flap. A 59-year-old Japanese woman was transferred to our hospital for evaluation of acute abdominal pain. She had a history of conservative treatment with antibiotics for spontaneous rupture of a liver cyst 1 month previously. On arrival, she exhibited abdominal tenderness and muscular defense. Enhanced computed tomography showed ascites and a large ruptured hepatic cyst (diameter of $10 \mathrm{~cm}$ ). We diagnosed rerupture of a liver cyst and performed laparotomy for cyst fenestration and intraperitoneal drainage. During the operation, we found the perforation site on the ventral side of the cyst and brown, muddled ascitic fluid. Cholangiography showed no bile leakage on the inner wall. Pathological investigation revealed no evidence of malignancy. The patient recovered without any adverse events and was discharged on postoperative day 8. No recurrences or complications occurred for 2 years.
\end{abstract}

Keywords: Nonparasitic liver cyst rupture; Cyst fenestration; Acute abdomen

\section{Background}

A nonparasitic liver cyst (NLC) is a common benign liver disease. It is potentially asymptomatic and is often incidentally diagnosed with abdominal imaging such as ultrasonography or computed tomography (CT). With the advancements and spread of these abdominal imaging techniques, NLCs are becoming more frequently detected and have been found in approximately $5 \%$ of the population [1]. In many cases, an NLC is asymptomatic and is conservatively followed up without treatment. However, NLCs are sometimes associated with various complications such as rupture, infection, hemorrhage, obstructive jaundice, portal hypertension, and pulmonary embolism. These complications occur in less than $5 \%$ of all patients with NLC [2].

We herein describe a rare case of spontaneous rerupture of an NLC that had become exacerbated after conservative treatment and was successfully treated with surgical fenestration.

\footnotetext{
* Correspondence: k_inoue@med.kyushu-u.ac.jp

'Department of Surgery and Science, Kyushu University, 3-1-1 Maidashi,

Fukuoka, Japan

${ }^{2}$ Department of Surgery, Fukuoka Higashi Medical Center, Koga, Japan
}

\section{Case presentation}

A 59-year-old Japanese woman was transferred to the emergency unit of our hospital for evaluation of acute abdominal pain. She had a history of conservative treatment for a spontaneous NLC rupture 1 month previously in another hospital (Fig. 1a).

On examination, she had a pulse rate of 115 beats/ min, blood pressure of $112 / 68 \mathrm{mmHg}$, and no fever. Her abdomen was flat but hard and painful. She also exhibited obvious tenderness and muscular defense upon arrival. Blood tests revealed acute inflammation and anemia (Table 1). The levels of the tumor markers carcinoembryonic antigen and carbohydrate antigen 19-9 were within normal limits. Enhanced CT showed hepatic cysts and ascites. The largest cyst was found on the lateral segment; it exhibited an irregularly shaped surface and was present within a partially high dense lesion (Fig. 1b). The cyst volume had obviously decreased during the 1-month period before presentation to our hospital (Fig. 1, below). However, no neoplastic features such as thickened walls, papillary projections, or calcifications were found. The ascitic fluid collected by abdominal puncture was brown and muddled. The bilirubin level of the ascitic fluid was normal; however, the

\section{然 Springer}



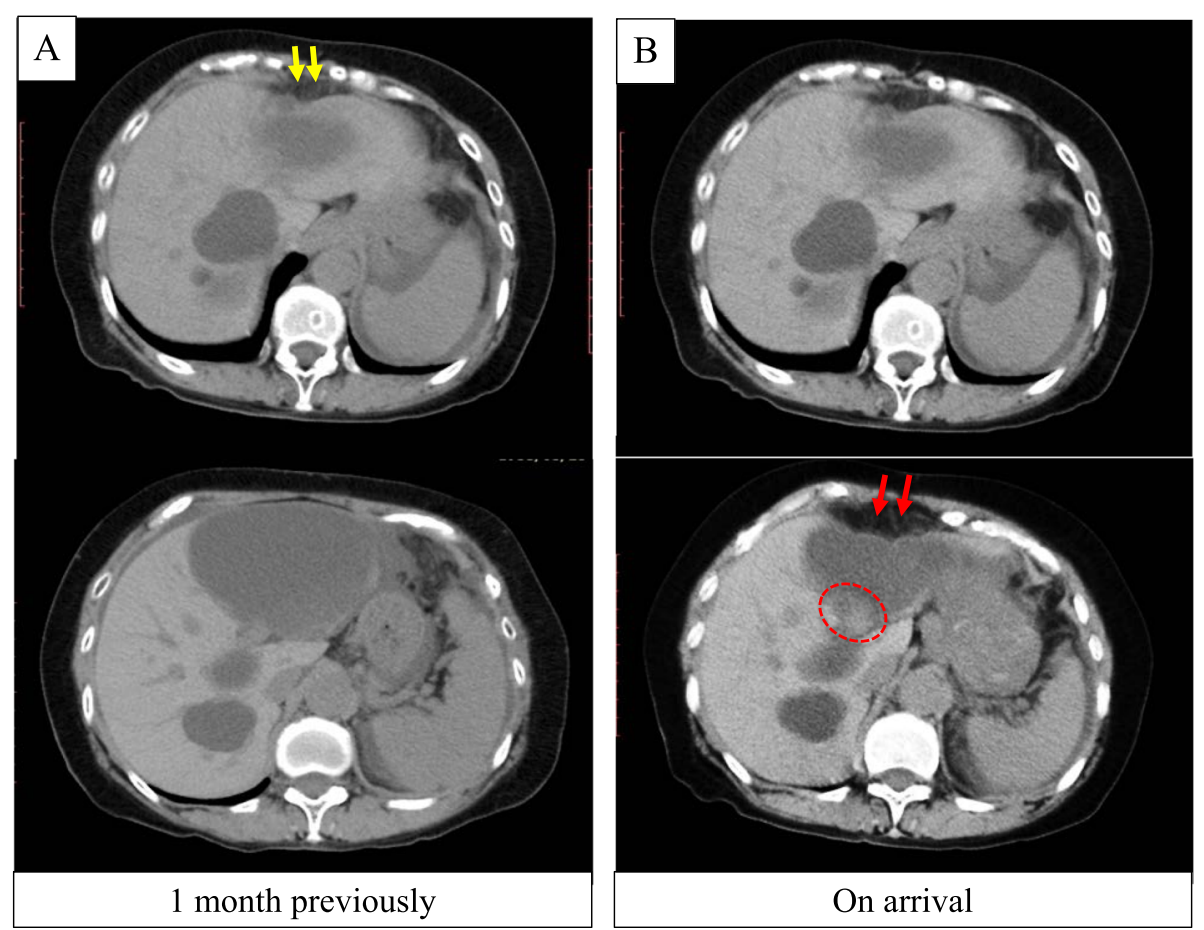

Fig. 1 CT images of progression of hepatic cyst rupture. a CT image 1 month before presentation to our hospital. The largest cyst showed an irregularly shaped wall on the ventral side (above, yellow arrows). At that time, the caudal part of the cyst kept circular (below). Some ascitic fluid was found around the spleen. $\mathbf{b}$ CT image on arrival to our hospital. Volume of the irregularly shaped cyst had obviously decreased (red arrows) and was present within a relatively high dense lesion (red circle)

neutrophil and hemoglobin levels were high. Bacterial culture of ascetic fluid was negative (Table 2).

Based on the patient's clinical course and investigation findings, we diagnosed panperitonitis associated with rerupture of the liver cyst and accompanied by hemorrhage.

Table 1 Blood examination on arrival

\begin{tabular}{lll}
\hline White blood cells & 17400 & $/ \mu \mathrm{l}$ \\
Neutrophil & 89.8 & $\%$ \\
Hemoglobin & 10.7 & $\mathrm{~g} / \mathrm{dl}$ \\
Platelets & 247,000 & $/ \mu \mathrm{l}$ \\
Albumin & 4.0 & $\mathrm{~g} / \mathrm{dl}$ \\
Total bilirubin & 0.53 & $\mathrm{mg} / \mathrm{dl}$ \\
Lactate dehydrogenase & 255 & $\mathrm{IU} / \mathrm{l}$ \\
Aspartate aminotransferase & 26 & $\mathrm{IU} / \mathrm{l}$ \\
Alanine transaminase & 24 & $\mathrm{IU} / \mathrm{l}$ \\
Alkaline phosphatase & 298 & $\mathrm{IU} / \mathrm{l}$ \\
Creatinine & 0.5 & $\mathrm{mg} / \mathrm{dl}$ \\
C-reactive protein & 0.26 & $\mathrm{mg} / \mathrm{dl}$ \\
Carcinoembryonic antigen & 2.5 & $\mathrm{ng} / \mathrm{ml}$ \\
Carbohydrate antigen 19-9 & $<2.0$ & $\mathrm{U} / \mathrm{ml}$ \\
a-fetoprotein & 4.9 & $\mathrm{ng} / \mathrm{ml}$ \\
\hline
\end{tabular}

Laparotomy was performed for cyst fenestration and intraperitoneal drainage.

During the operation, we found the perforation site on the ventral side of the cyst (Fig. 2). The perforation was approximately $3 \mathrm{~cm}$, and the cyst wall was fibrous. Although no obvious hematoma was detected, approximately $600 \mathrm{ml}$ of ascitic fluid was found. The ascitic fluid was brown and slightly muddled. No nodules or other specific findings, indicating signs of malignancy, were found. We resected the ventral wall of the cyst followed by cholecystectomy and cholangiography. Cholangiography showed no bile leakage on the inner wall. We performed cyst argon beam coagulator ablation of the inner wall and covered the site with an omental transposition flap. The patient tolerated these procedures well and was transferred to the intensive care unit in a hemodynamically

Table 2 Examination of ascitic fluid on arrival

\begin{tabular}{lll}
\hline Property & \multicolumn{1}{l}{ Brown and slightly muddled } \\
\hline Cell counts & 43980 & $/ \mu l$ \\
Neutrophils & 88 & $\%$ \\
Total bilirubin & $<0.01$ & $\mathrm{mg} / \mathrm{dl}$ \\
Hemoglobin & 1.0 & $\mathrm{~g} / \mathrm{dl}$ \\
Bacterial culture & Negative & \\
\hline
\end{tabular}




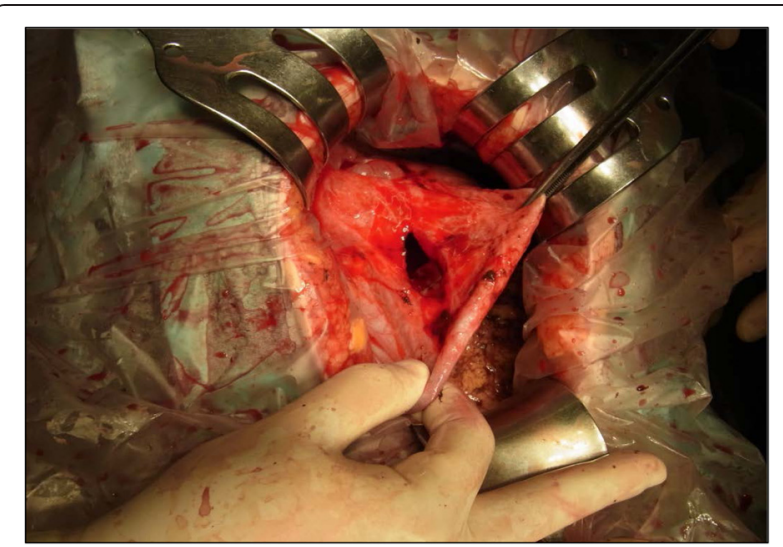

Fig. 2 Perforation lesion of hepatic cyst. The perforation lesion was on the ventral side of the cyst. The lesion was approximately $3 \mathrm{~cm}$, and the cyst wall was fibrous

stable condition. Pathological examination showed only fibrous connective tissue covered with simple cuboidal epithelium; there was no evidence of malignancy (Fig. 3). The patient received antibiotics (PIPC/TAZ) until postoperative day 5 . She recovered without any adverse events and was discharged on postoperative day 8. She was in good condition without recurrent symptoms 2 years postoperatively.

\section{Conclusions}

Rupture of parasitic liver cysts, which are mainly caused by the Echinococcus species, is a well-known complication of such cysts and is often reported as hydatid cyst rupture [3, 4]. In contrast, rupture of NLCs is highly rare. The frequency is unknown, but Morgenstern [5] stated that only four cases of rupture are present among approximately 250 reports of solitary NLC published before 1958. In our computerized search of Englishlanguage reports of NLC rupture published from 1959 to 2013, we identified only 17 publications describing NLC rupture (Table 3) [3-19]. The causes of NLC rupture are variable and include infection, trauma, iatrogenic injury, and spontaneity $[11,16,20]$. In the current report, we presented a case of the second rupture without a specific cause such as infection or trauma after previous conservative treatment. The patient had acute abdomen and signs of preshock on arrival; clinical investigations showed mild anemia, acute systemic inflammation, and muddy ascitic fluid. The preoperative CT showed an irregularly shaped NLC with a high dense lesion. Therefore, we diagnosed the spontaneous rerupture of the NLC with hemorrhage and performed acute surgery. As intraoperative findings, no obvious hematoma was detected. However, comparing with the previous reports in Table 3, brown muddled ascites indicated the presence of hemorrhage. Therefore, in our case, the slight bleeding in the ruptured NLC could exist, and it might be the reason why the patient exhibited the acute abdomen.

In general, treatment options for symptomatic NLCs include surgical procedures and conservative management such as percutaneous needle aspiration and drainage [21]. Percutaneous needle aspiration is a less invasive intervention than a surgical operation and can also be used to examine the properties of the cyst contents. However, it is associated with high relapse rates of $>80 \%$. This high recurrence rate can be decreased by about $20 \%$ when percutaneous needle aspiration is combined with alcohol minocycline chloride or tetracycline chloride injection $[22,23]$. In our case, the patient underwent the only conservative management after the initial rupture of NLC without any adjunctive procedures. This could be one reason why the rerupture occurred. With respect to surgical management, open or laparoscopic cyst fenestration, also termed deroofing, is a definitive and widespread treatment [24]. Argon beam coagulation and electrocoagulation to destroy the remaining epithelium and placement of an omental transposition flap after fenestration can also contribute to reduced relapse rates [25]. Complete cyst excision and partial hepatectomy have been performed in some cases because of concern regarding malignancy. However,
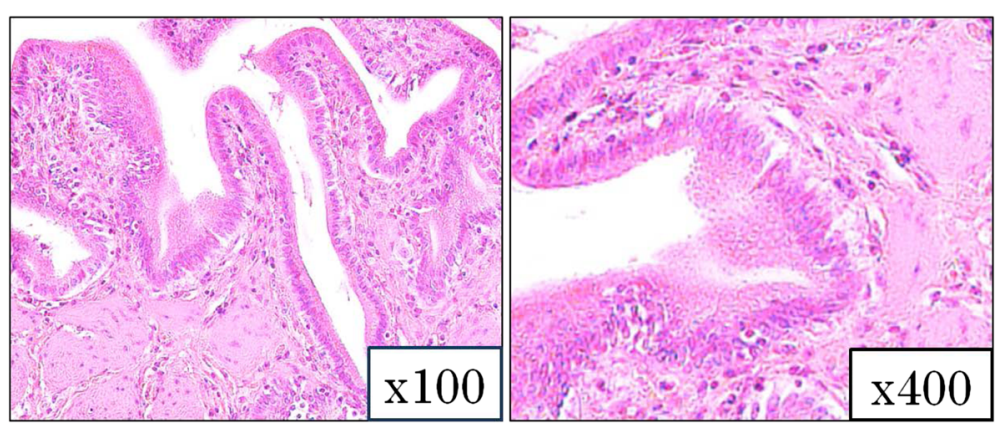

Fig. 3 Pathological examination of cyst wall. Only fibrous connective tissue covered with simple cuboidal epithelium was observed; no evidence of malignancy was present 
Table 3 Review of nonparasitic liver cyst rupture

\begin{tabular}{|c|c|c|c|c|c|c|c|c|c|c|c|c|c|}
\hline Year & Reference & Age & Sex & Symptoms & $\begin{array}{l}\text { Peritoneal } \\
\text { irritation }\end{array}$ & Cyst (cm) & $\begin{array}{l}\text { Location } \\
\text { (segments) }\end{array}$ & Ascites & property of ascites & Hemorrhage & $\begin{array}{l}\text { Emergency } \\
\text { procedures }\end{array}$ & Treatment & Outcome \\
\hline \multirow[t]{2}{*}{2014} & Our case & 59 & $\mathrm{~F}$ & $\begin{array}{l}\text { Acute abdominal } \\
\text { pain }\end{array}$ & Yes & 10 & Left & Yes & $\begin{array}{l}\text { Brown and } \\
\text { slightly muddled }\end{array}$ & $\begin{array}{l}\text { No active } \\
\text { bleeding }\end{array}$ & Yes & $\begin{array}{l}\text { Laparotomy and } \\
\text { cyst fenestration }\end{array}$ & Uneventful \\
\hline & & & & $\begin{array}{l}\text { Tenderness and } \\
\text { muscular defense }\end{array}$ & & & & & & & & $\begin{array}{l}\text { Placing } \\
\text { omentum over } \\
\text { the ruptured cyst }\end{array}$ & \\
\hline \multirow[t]{4}{*}{2013} & Marion & 37 & $\mathrm{~F}$ & $\begin{array}{l}\text { Pain in the right } \\
\text { hypochondrium }\end{array}$ & No & 18 & $\begin{array}{l}\text { Right lobe } \\
\text { S4 }\end{array}$ & Yes & $\begin{array}{l}\text { Hemoperitoneum } \\
\text { blood clots }\end{array}$ & Yes & Yes & Cystectomy & Uneventful \\
\hline & & & & $\begin{array}{l}\text { Tenderness in the } \\
\text { right subcostal } \\
\text { region }\end{array}$ & & & & & & & & & \\
\hline & & & & Pallor & & & & & & & & & \\
\hline & & & & Dyspnea & & & & & & & & & \\
\hline \multirow[t]{2}{*}{2010} & Ueda & 64 & $\mathrm{~F}$ & $\begin{array}{l}\text { Right upper } \\
\text { quadrant pain }\end{array}$ & No & 10 & Right lobe & Yes & Serous brown & No & No & $\begin{array}{l}\text { Percutaneous } \\
\text { aspiration }\end{array}$ & Uneventful \\
\hline & & & & & & & & & & & & $\begin{array}{l}\text { Injection of } \\
\text { minocycline } \\
\text { hydrochloride }\end{array}$ & \\
\hline \multirow[t]{3}{*}{2010} & Miliadis & 70 & M & $\begin{array}{l}\text { Sudden diffuse } \\
\text { abdominal pain }\end{array}$ & Yes & 13 & Right lobe & Yes & $\begin{array}{l}\text { Opaque-yellowish } \\
\text { peritoneal fluid }\end{array}$ & Unknown & Yes & $\begin{array}{l}\text { Deroofing of the } \\
\text { cyst }\end{array}$ & Uneventful \\
\hline & & & & Diffuse guarding & & & & & & & & Omentoplasty & \\
\hline & & & & $\begin{array}{l}\text { Rebound } \\
\text { tenderness }\end{array}$ & & & & & & & & Cholecystectomy & \\
\hline \multirow[t]{5}{*}{2007} & Salemis & 50 & M & $\begin{array}{l}\text { Sudden severe } \\
\text { abdominal pain }\end{array}$ & Yes & 17 & Left lobe & Yes & Unknown & Unknown & Yes & $\begin{array}{l}\text { Wide excision of } \\
\text { the cyst }\end{array}$ & Uneventful \\
\hline & & & & Nausea & & & & & & & & Running locking & \\
\hline & & & & Vomiting & & & & & & & & $\begin{array}{l}\text { suture along the } \\
\text { edge of the }\end{array}$ & \\
\hline & & & & Diffuse tenderness & & & & & & & & resected cyst wall & \\
\hline & & & & $\begin{array}{l}\text { Rebound } \\
\text { tenderness }\end{array}$ & & & & & & & & & \\
\hline 2005 & Cheung & 73 & $\mathrm{~F}$ & $\begin{array}{l}\text { Sever abdominal } \\
\text { pain }\end{array}$ & Yes & 17 & Right lobe & Yes & Blood stained & Yes & Yes & $\begin{array}{l}\text { Laparoscopic } \\
\text { deroofing of } \\
\text { ruptured cyst }\end{array}$ & Good condition \\
\hline 2003 & Shutsha & 67 & $\mathrm{~F}$ & $\begin{array}{l}\text { Sudden sharp } \\
\text { abdominal pain in } \\
\text { the right upper } \\
\text { abdomen after } \\
\text { coughing fit }\end{array}$ & No & Unknown & Multiple & Yes & Unknown & No & - & $\begin{array}{l}\text { None because } \\
\text { abdominal pain } \\
\text { spontaneously } \\
\text { disappeared } \\
\text { within } 2 \text { days }\end{array}$ & Good condition \\
\hline
\end{tabular}


Table 3 Review of nonparasitic liver cyst rupture (Continued)

\begin{tabular}{|c|c|c|c|c|c|c|c|c|c|c|c|c|c|}
\hline \multirow[t]{3}{*}{2003} & \multirow[t]{3}{*}{ Kanazawa } & \multirow[t]{3}{*}{78} & \multirow[t]{3}{*}{ M } & \multirow{2}{*}{$\begin{array}{l}\text { Sudden onset of } \\
\text { sever right } \\
\text { hypochondralgia }\end{array}$} & \multirow[t]{3}{*}{ No } & \multirow[t]{3}{*}{ Unknown } & \multirow[t]{3}{*}{ Right lobe } & \multirow[t]{3}{*}{ Yes } & \multirow{3}{*}{$\begin{array}{l}\text { Dark, bloody- } \\
\text { colored pus }\end{array}$} & \multirow{3}{*}{$\begin{array}{l}\text { Yes } \\
\text { intracystic }\end{array}$} & \multirow[t]{3}{*}{ No } & Antibiotics & \multirow[t]{3}{*}{ Good condition } \\
\hline & & & & & & & & & & & & $\begin{array}{l}\text { Drainage and } \\
\end{array}$ & \\
\hline & & & & $\begin{array}{l}\text { Tenderness in the } \\
\text { right } \\
\text { hypochondral } \\
\text { region without } \\
\text { muscle defense }\end{array}$ & & & & & & & & & \\
\hline \multirow[t]{3}{*}{2002} & \multirow[t]{3}{*}{ Ishikawa } & \multirow[t]{3}{*}{42} & \multirow[t]{3}{*}{$\mathrm{F}$} & \multirow[t]{3}{*}{$\begin{array}{l}\text { Discomfort in } \\
\text { upper abdomen }\end{array}$} & \multirow[t]{3}{*}{ No } & 10 & \multirow[t]{3}{*}{ S4 and S5 } & \multirow[t]{3}{*}{ Yes } & \multirow[t]{3}{*}{$\begin{array}{l}\text { Muddy, dark } \\
\text { brown }\end{array}$} & \multirow[t]{3}{*}{ Yes } & \multirow[t]{3}{*}{ No } & $\begin{array}{l}\text { Transcatheter } \\
\text { arterial } \\
\text { embolization } \\
\text { (TAE) }\end{array}$ & \multirow[t]{3}{*}{ Uneventful } \\
\hline & & & & & & \multirow{2}{*}{$\begin{array}{l}13 \text { after } \\
\text { TAE }\end{array}$} & & & & & & Drainage & \\
\hline & & & & & & & & & & & & Cystectomy & \\
\hline \multirow[t]{3}{*}{2002} & \multirow[t]{3}{*}{ Carel } & \multirow[t]{3}{*}{76} & \multirow[t]{3}{*}{ M } & $\begin{array}{l}\text { Progressive } \\
\text { abdominal pain }\end{array}$ & \multirow[t]{3}{*}{ Yes } & \multirow[t]{3}{*}{9} & Right lobe & Yes & hemoperitoneum & Yes & Yes & Laparotomy & $\begin{array}{l}\text { Death } 4 \text { weeks after } \\
\text { admission due to }\end{array}$ \\
\hline & & & & Severe tenderness & & & & & & & & Placing & $\begin{array}{l}\text { complications } \\
\text { (hemodynamic instability, }\end{array}$ \\
\hline & & & & $\begin{array}{l}\text { Diffuse rebound } \\
\text { pain }\end{array}$ & & & & & & & & the ruptured cyst & $\begin{array}{l}\text { arrhythmias, bacterial } \\
\text { pneumonia) }\end{array}$ \\
\hline 1999 & Yamaguchi & 61 & M & Spontaneous pain & Yes & 13 & Left and & Yes & With blood clot & Yes & no & Hepatectomy & Uneventful \\
\hline & & & & $\begin{array}{l}\text { quadrant of the } \\
\text { abdomen }\end{array}$ & & & & & $\begin{array}{l}\text { No preoperative } \\
\text { investigation }\end{array}$ & & & $\begin{array}{l}\text { anterior branch } \\
\text { of right portal }\end{array}$ & \\
\hline & & & & Tenderness & & & & & & & & & \\
\hline & & & & Muscular defense & & & & & & & & & \\
\hline 1999 & Payatakes & 62 & unknown & Acute right upper & - & 9.5 & Right & - & - & - & - & Partial excision & Symptom free \\
\hline & & & & abdominal pain & & & & & & & & External drainage & \\
\hline 1989 & Akriviadis & 48 & $\mathrm{~F}$ & $\begin{array}{l}\text { Sever epigastric } \\
\text { pain }\end{array}$ & - & Unknown & Left & - & - & - & No & Conservatively & Uneventful \\
\hline 1988 & Ayyash & 36 & M & $\begin{array}{l}\text { Sudden epigastric } \\
\text { pain }\end{array}$ & - & 4 & Right & - & - & - & No & Conservatively & Uneventful \\
\hline & & & & Vomiting & & & & & & & & & \\
\hline 1974 & Brunes & 54 & $\mathrm{~F}$ & $\begin{array}{l}\text { Diffuse abdominal } \\
\text { pain }\end{array}$ & - & 25 & Left & - & - & - & - & $\begin{array}{l}\text { Partial removal of } \\
\text { the ruptured cyst }\end{array}$ & Symptom free \\
\hline 1972 & Russell & 68 & M & $\begin{array}{l}\text { Sudden severe } \\
\text { abdominal pain }\end{array}$ & - & 12 & Left & - & - & - & - & Left lobectomy & Uneventful \\
\hline
\end{tabular}


Table 3 Review of nonparasitic liver cyst rupture (Continued)

\begin{tabular}{|c|c|c|c|c|c|c|c|c|c|c|c|c|c|}
\hline \multirow[t]{2}{*}{1960} & Johnston & 82 & $\mathrm{~F}$ & $\begin{array}{l}\text { Right-sided } \\
\text { abdominal pain }\end{array}$ & - & 15 & Right & - & - & - & - & $\begin{array}{l}\text { Catheter } \\
\text { drainage }\end{array}$ & $\begin{array}{l}\text { Died on third } \\
\text { postoperative day }\end{array}$ \\
\hline & & & & Vomiting & & & & & & & & & \\
\hline \multirow[t]{2}{*}{1959} & Morgenstern & 56 & F & $\begin{array}{l}\text { Sudden severe } \\
\text { abdominal pain }\end{array}$ & Yes & 35 & Left & Yes & $\begin{array}{l}\text { Dark greenish } \\
\text { brown }\end{array}$ & Unknown & Yes & Lobectomy & Uneventful \\
\hline & & & & No vomiting & & & & & & & & $\begin{array}{l}\text { Decompressing } \\
\text { cholecystostomy }\end{array}$ & \\
\hline
\end{tabular}


these operations are highly invasive and almost unacceptable for benign diseases despite the fact that the reported recurrence rate is $0 \%[11,25]$. Therefore, in the present case, we performed emergent laparotomy, cyst fenestration, argon beam coagulation of the remaining cyst wall, and placement of an omental transposition flap.

The optimal treatment strategy and surgical indications for NLC rupture are not clearly defined. Conservative management including percutaneous drainage might be useful for cases without critical features such as signs of peritoneal irritation and shock [7]. However, as shown in the current case, rerupture of an NLC after conservative treatment should be considered. In terms of curability, the risk of relapse, and the possibility of other complications such as hemorrhage, cyst fenestration might be more favorable in most cases.

In conclusion, rupture of an NLC is a highly rare complication but can be a cause of the acute abdomen. Clinical observation and conservative treatment including percutaneous needle aspiration and drainage might be beneficial; however, careful consideration of the optimal therapy and performance of close follow-up are necessary owing to the possibility of relapse.

\section{Consent}

Written informed consent was obtained from the patient for publication of this case report and any accompanying images. A copy of the written consent is available for review by the Editor-in-Chief of this journal.

\section{Abbreviations}

CT: computed tomography; NLC: nonparasitic liver cyst.

\section{Competing interests}

The authors declare that they have no competing interests.

\section{Authors' contributions}

$\mathrm{KI}$ treated the patient and wrote the manuscript. TI performed the operation and organized the writing of the manuscript. SI and TO performed the operation and treated the patient. TN, KS, TE, and YM organized the writing of the manuscript. All authors read and approved the final manuscript.

\section{Authors' information}

$\mathrm{KI}$ is a surgery fellow and belongs to Department of Surgery and Science, Kyushu University. Kl, TI, and SI were members of department of surgery in Fukuoka Higashi Medical Center. TO, TN, and TE are members of department of surgery in Fukuoka Higashi Medical Center. KS and YM are members of Department of Surgery and Science, Kyushu University.

\section{Acknowledgements}

We thank Dr. Sueishi, a pathology faculty member, for the initial pathologic diagnosis of the patient of this case report.

Received: 20 April 2015 Accepted: 21 August 2015

Published online: 02 September 2015

\section{References}

1. Caremani M, Vincenti A, Benci A, Sassoli S, Tacconi D. Ecographic epidemiology of non-parasitic hepatic cysts. J Clin Ultrasound. 1993;21(2):115-8.
2. Macutkiewicz C, Plastow R, Chrispijn M, Filobbos R, Ammori BA, Sherlock DJ, et al. Complications arising in simple and polycystic liver cysts. World J Hepatol. 2012;4:406-11.

3. Johnston JP. Solitary nonparasitic cyst of the liver with rupture. Harper Hosp Bull. 1960;18:318-20.

4. Ueda J, Yoshida H, Taniai N, Mineta S, Kawano Y, Uchida E. A case of spontaneous rupture of a simple hepatic cyst. J Nippon Med Sch. 2010;77:181-5.

5. Morgenstern L. Rupture of solitary nonparasitic cysts of the liver. Ann Surg. 1959;150:167-71.

6. Payatakes AH, Kakkos SK, Solomou EG, Tepetes KN, Karavias DD. Surgical treatment of non-parasitic hepatic cysts: report of 12 cases. Eur J Surg. 1999;165:1154-8.

7. Akriviadis EA, Steindel H, Ralls P, Redeker AG. Spontaneous rupture of nonparasitic cyst of the liver. Gastroenterology. 1989;97:213-5.

8. Ayyash K, Haddad J. Spontaneous rupture of a solitary nonparasitic cyst of the liver. Case Report Acta Chir Scand. 1988;154:241-3.

9. Brunes $L$. Rupture of a solitary nonparasitic cyst of the liver. Report of a case. Acta Chir Scand. 1974;140:159-60.

10. Russell RC. Ruptured solitary cyst of the liver. Br I Surg. 1972;59:919-20.

11. Miliadis L, Giannakopoulos T, Boutsikos G, Terzis I, Kyriazanos ID. Spontaneous rupture of a large non-parasitic liver cyst: a case report. J Med Case Rep. 2010;4:2.

12. Salemis NS, Georgoulis E, Gourgiotis S, Tsohataridis E. Spontaneous rupture of a giant non parasitic hepatic cyst presenting as an acute surgical abdomen. Ann Hepatol. 2007;6:190-3.

13. Cheung FK, Lee KF, John W, Lai PB. Emergency laparoscopic unroofing of a ruptured hepatic cyst. JSLS. 2005;9:497-9.

14. Shutsha E, Brenard R. Hepatic cyst rupture after a coughing fit. J Hepatol. 2003;38:870.

15. Kanazawa A, Yoshioka Y, Inoi O, Kubo S, Kinoshita H. Intracystic hemorrhage with spontaneous rupture of liver cyst complicated by infection: a case report. Osaka City Med J. 2003;49:57-60.

16. Ishikawa H, Uchida S, Yokokura Y, Iwasaki Y, Horiuchi H, Hiraki M, et al. Nonparasitic solitary huge liver cysts causing intracystic hemorrhage or obstructive jaundice. J Hepatobiliary Pancreat Surg. 2002;9:764-8.

17. Carels RA, van Bommel EF. Ruptured giant liver cyst: a rare cause of acute abdomen in a haemodialysis patient with autosomal dominant polycystic kidney disease. Neth J Med. 2002;60:363-5.

18. Yamaguchi M, Kuzume M, Matsumoto T, Matsumiya A, Nakano H, Kumada K. Spontaneous rupture of a nonparasitic liver cyst complicated by intracystic hemorrhage. J Gastroenterol. 1999;34:645-8.

19. Marion Y, Brevartt C, Plard L, Chiche L. Hemorrhagic liver cyst rupture: an unusual life-threatening complication of hepatic cyst and literature review. Ann Hepatol. 2013;12:336-9.

20. Nunnari G, Pinzone MR, Gruttadauria S, Celesia BM, Madeddu G, Malaguarnera G, et al. Hepatic echinococcosis: clinical and therapeutic aspects. World J Gastroenterol. 2012;18:1448-58.

21. Tikkakoski T, Makela JT, Leinonen S, Paivansalo M, Merikanto J, Karttunen A, et al. Treatment of symptomatic congenital hepatic cysts with single-session percutaneous drainage and ethanol sclerosis: technique and outcome. J Vasc Interv Radiol. 1996;7:235-9.

22. Yoshida H, Onda M, Tajiri T, Arima Y, Mamada Y, Taniai N, et al. Long-term results of multiple minocycline hydrochloride injections for the treatment of symptomatic solitary hepatic cyst. J Gastroenterol Hepatol. 2003;18:595-8.

23. Garcea G, Pattenden CJ, Stephenson J, Dennison AR, Berry DP. Nine-year single-center experience with nonparastic liver cysts: diagnosis and management. Dig Dis Sci. 2007;52:185-91.

24. Tocchi A, Mazzoni G, Costa G, Cassini D, Bettelli E, Agostini N, et al. Symptomatic nonparasitic hepatic cysts: options for and results of surgical management. Arch Surg. 2002;137:154-8.

25. Emmermann A, Zornig C, Lloyd DM, Peiper M, Bloechle C, Broelsch CE. Laparoscopic treatment of nonparasitic cysts of the liver with omental transposition flap. Surg Endosc. 1997;11:734-6. 